\title{
Article \\ Functional Dysregulations in CA1 Hippocampal Networks of a 3-Hit Mouse Model of Schizophrenia
}

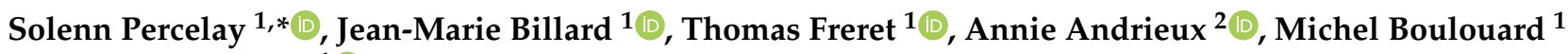 \\ and Valentine Bouet ${ }^{1}$ (D) \\ 1 UNICAEN, INSERM, COMETE, CYCERON, CHU Caen, Normandie Université, 14000 Caen, France; \\ jean-marie.billard@inserm.fr (J.-M.B.); thomas.freret@unicaen.fr (T.F.); michel.boulouard@unicaen.fr (M.B.); \\ valentine.bouet@unicaen.fr (V.B.) \\ 2 Inserm U1216, CEA, Grenoble Institut Neurosciences, Université Grenoble Alpes, 38000 Grenoble, France; \\ annie.andrieux@univ-grenoble-alpes.fr \\ * Correspondence: solenn.percelay@unicaen.fr; Tel.: +2-31-56-68-72
}

Citation: Percelay, S.; Billard, J.-M.; Freret, T.; Andrieux, A.; Boulouard,

M.; Bouet, V. Functional

Dysregulations in CA1 Hippocampal Networks of a 3-Hit Mouse Model of Schizophrenia. Int. J. Mol. Sci. 2021, 22, 2644. https://doi.org/10.3390/ ijms22052644

Academic Editor: Changjong Moon

Received: 19 January 2021

Accepted: 2 March 2021

Published: 5 March 2021

Publisher's Note: MDPI stays neutral with regard to jurisdictional claims in published maps and institutional affiliations.

Copyright: (c) 2021 by the authors. Licensee MDPI, Basel, Switzerland. This article is an open access article distributed under the terms and conditions of the Creative Commons Attribution (CC BY) license (https:// creativecommons.org/licenses/by/ $4.0 /)$.

\begin{abstract}
For a better translation from treatment designs of schizophrenia to clinical efficiency, there is a crucial need to refine preclinical animal models. In order to consider the multifactorial nature of the disorder, a new mouse model associating three factors (genetic susceptibility-partial deletion of the MAP6 gene, early-life stress-maternal separation, and pharmacological treatmentchronic $\Delta$-9-tetrahydrocannabinol during adolescence) has recently been described. While this model depicts a schizophrenia-like phenotype, the neurobiological correlates remain unknown. Synaptic transmission and functional plasticity of the CA1 hippocampal region of male and female 3-hit mice were therefore investigated using electrophysiological recordings on the hippocampus slice. While basal excitatory transmission remained unaffected, NMDA receptor (NMDAr)-mediated long-term potentiation (LTP) triggered by theta-burst (TBS) but not by high-frequency (HFS) stimulation was impaired in 3-hit mice. Isolated NMDAr activation was not affected or even increased in female 3-hit mice, revealing a sexual dimorphism. Considering that the regulation of LTP is more prone to inhibitory tone if triggered by TBS than by HFS, the weaker potentiation in 3-hit mice suggests a deficiency of intrinsic GABA regulatory mechanisms. Indeed, NMDAr activation was increased by $\mathrm{GABA}_{\mathrm{A}}$ receptor blockade in wild-type but not in 3-hit mice. This electrophysiological study highlights dysregulations of functional properties and plasticity in hippocampal networks of 3-hit mice, one of the mechanisms suspected to contribute to the pathophysiology of schizophrenia. It also shows differences between males and females, supporting the sexual dimorphism observed in the disorder. Combined with the previously reported study, the present data reinforce the face validity of the 3-hit model that will help to consider new therapeutic strategies for psychosis.
\end{abstract}

Keywords: psychiatric disorder; hippocampus; functional plasticity; long term potentiation; NMDA receptor

\section{Introduction}

Schizophrenia is a debilitating pathology that affects approximately $1 \%$ of the population. It is characterized by symptoms described as positive and negative, accompanied by cognitive deficits [1]. While treatments with typical and atypical antipsychotics are relevant for positive symptoms, they are questioned for negative symptoms and poorly effective for cognitive impairments [2,3]. One major obstacle for the development of potent new treatments against schizophrenia is the absence of relevant and fully recognized animal models of the disorder. Indeed, even if a wide range of rodent models already exists, their construct validity may be questioned since they are mostly based on one sole risk factor [4-6]. Using a sole factor does not fit with the idea that schizophrenia would result from a combination of genetic vulnerability and neurodevelopmental insults affecting neurotransmission systems [7]. It has been therefore recommended to use animal 
models with the highest construct validity respecting this multifactorial origin [8-11]. In this context, a 3-hit mouse model has recently been described, which associates a genetic susceptibility with an early developmental stress and a late pharmacological insult [12]. More precisely, a partial deletion of the microtubule-associated protein MAP6 gene, a transient maternal separation (for $24 \mathrm{~h}$ at the age of 9-days), and a chronic administration of $\Delta$-9-tetrahydrocannabinol (THC, $8 \mathrm{mg} / \mathrm{kg}$ daily during adolescence) have been associated [13-15], postulating that the three factors will combine and synergize to trigger the mimicking-disorder. A recent investigation indicated that this 3-hit model displays some key-elements of the negative- and cognitive-like deficits expected: sociability deficit and cognitive deficits such as working memory impairment and alteration of reference memory, and a decrease in hippocampus volume [12]. Knowing whether changes in functional properties of synapses occur in 3-hit mice represents a major milestone to progress our knowledge of the pathophysiology of schizophrenia. In addition, investigating males and females in order to take into account the sexual dimorphism reported in patients, which is rarely done in animal models, is of importance [16,17].

The present study reveals alterations of both glutamate and GABA-mediated regulation of functional plasticity at CA3/CA1 hippocampal synapses of 3-hit mice that are differentially expressed in males and females. Together with the recently provided characterization, our functional analysis argues to consider the 3-hit conditioning as a relevant strategy to investigate schizophrenia-related phenotype.

\section{Results}

\subsection{Basal Synaptic Transmission}

The synaptic efficacy of basal non-N-methyl-D-aspartate receptor (non-NMDAr)mediated neurotransmission was considered in a first step. This was assessed by determining field excitatory postsynaptic potentials / presynaptic fiber volleys ratio (fEPSP/PFV ratio) thus considered as an index of synaptic efficacy (Ise). Ise calculated for three increasing stimulus intensities was not statistically different in 3-hit mice compared to Wild Type (WT) mice, neither in males nor in females (Figure 1A). Additionally, no difference between males and females was found when WT or 3-hit groups were considered, respectively.
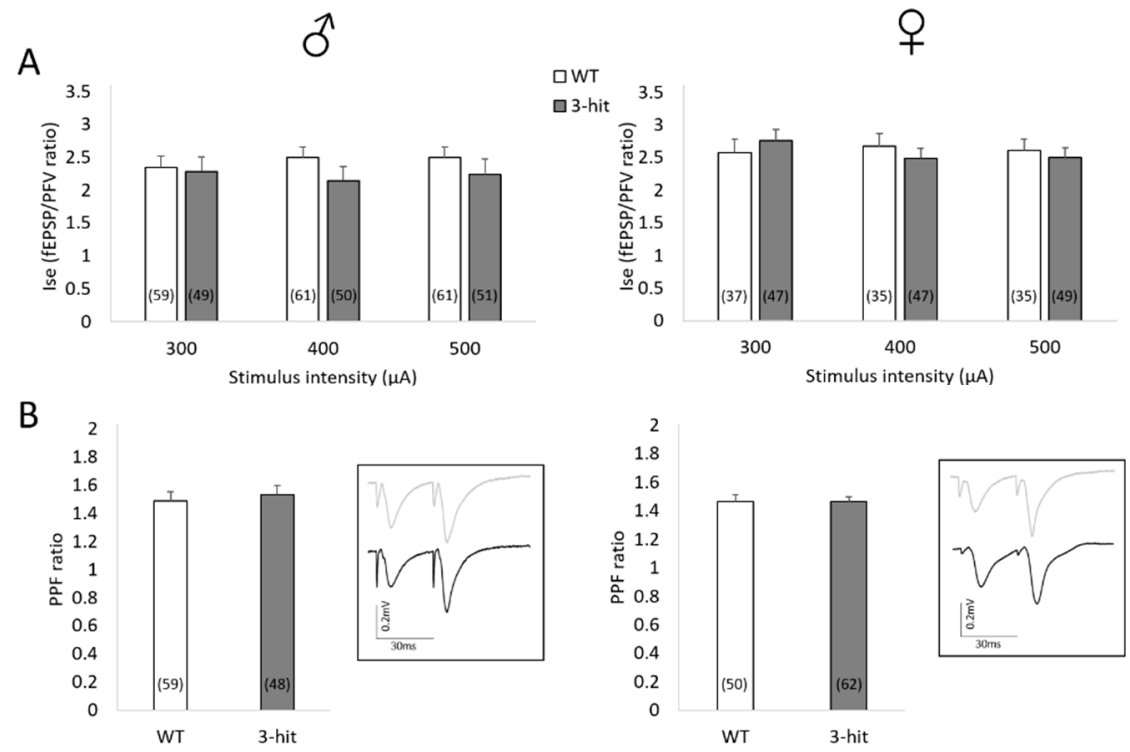

Figure 1. Basal synaptic transmission in CA1 hippocampal area is not impaired in 3-hit mice. (A) Index of synaptic efficacy Ise (fEPSP/PFV ratio) in Wild Type (WT) and 3-hit mice, males (left) and females (right), with increasing stimulus intensity. (B) Paired pulse facilitation (PPF) ratio in WT and 3-hit mice, males (left) and females (right). In inserts, traces recorded are shown: WT (grey line) and 3-hit (black line) male (left) and a female (right) mouse. The number of slices used in each group is indicated in histogram bars. Represented data are Mean \pm SEM. 


\subsection{Paired-Pulse Facilitation}

Basal neurotransmission closely depends on presynaptic release of glutamate, which was assessed by the paired-pulse facilitation (PPF) sowed paradigm (see Figure 1B, insert). As illustrated in Figure 1B, PPF ratio was not statistically different between WT and 3-hit mice. Furthermore, no difference in PPF ratio between males and females was shown within each experimental group.

Taken together, these results indicate that the 3-hit conditioning does not impact the basal neuronal communication in CA1 hippocampal networks, neither in males nor in females.

\subsection{Functional Plasticity}

In a second step, the effects of 3-hit conditioning on the expression of functional plasticity in CA1 hippocampal networks have been considered using different paradigms of tetanus stimulation.

High frequency stimulation (HFS)-related conditioning stimulation induced long-term potentiation (LTP) in WT and 3-hit mice of both genders (Figure 2A) since the differences between the baseline and the last $15 \mathrm{~min}$ of recordings were significant in all experimental groups $(p<0.001)$. The magnitude of HFS-induced LTP was not different between WT and 3-hit male (WT: $129.4 \pm 8.0 \%$ of baseline vs. 3-hit: $130.2 \pm 9.6 \%$, mean \pm SEM; neither group effect, time effect or time $x$ group interaction) and female mice (WT: $123.9 \pm 6.7 \%$ of baseline vs. 3-hit: $132.7 \pm 10.9 \%$, mean \pm SEM; neither group effect, time effect or time $x$ group interaction) (Figure 2A). Furthermore, comparison of male vs. female WTs showed higher amplitude in the former $(p<0.001)$. No difference was found between male and female 3-hit.

Theta-burst stimulation (TBS) also induced a long-lasting potentiation of synaptic transmission of both WT and 3-hit groups (Figure 2B). Indeed, statistical analysis between the baseline and the last $15 \mathrm{~min}$ of recordings showed a significant increase in fEPSP magnitude in all experimental groups $(p<0.001)$. However, in contrast to HFS, when intergroup comparison was considered, the magnitude of TBS-induced LTP was significantly lower in the 3-hit group than in the WT. This decrease was found in both males (WT: 138.8 $\pm 8.9 \%$ of baseline vs. 3-hit: $122.8 \pm 6.2 \%$, mean \pm SEM; group effect $p<0.001$, neither time effect or time $x$ group interaction) and females (WT: $141.5 \pm 9.6 \%$ of baseline vs. 3-hit: $134.0 \pm 4.6 \%$, mean \pm SEM; group effect $p<0.001$, neither time effect or time $\mathrm{x}$ group interaction) (Figure 2B). Furthermore, by comparing male and female, we found higher amplitude in females in the WT group as well as in the 3-hit group $(p<0.001)$.

Statistical differences for the two paradigms of conditioning stimulations were also found for the first $10 \mathrm{~min}$ post tetanus. After HFS, a significant decrease in this short-term potentiation (STP) occurred in 3-hit males $(p<0.001)$ but not in 3-hit females compared to WTs (Figure 2A). Whereas STP magnitude was similar in male and female WT mice, females 3-hit have higher STP than males $(p<0.001)$.

On the contrary, STP was significantly decreased in both male and female 3-hit mice compared to WT after TBS ( $p<0.001)$, as observed for LTP expression (Figure 2B). In this stimulation protocol, no difference in STP magnitude was found between males and females in the WT group as well as in the 3-hit group. 
A. HFS-induced LTP
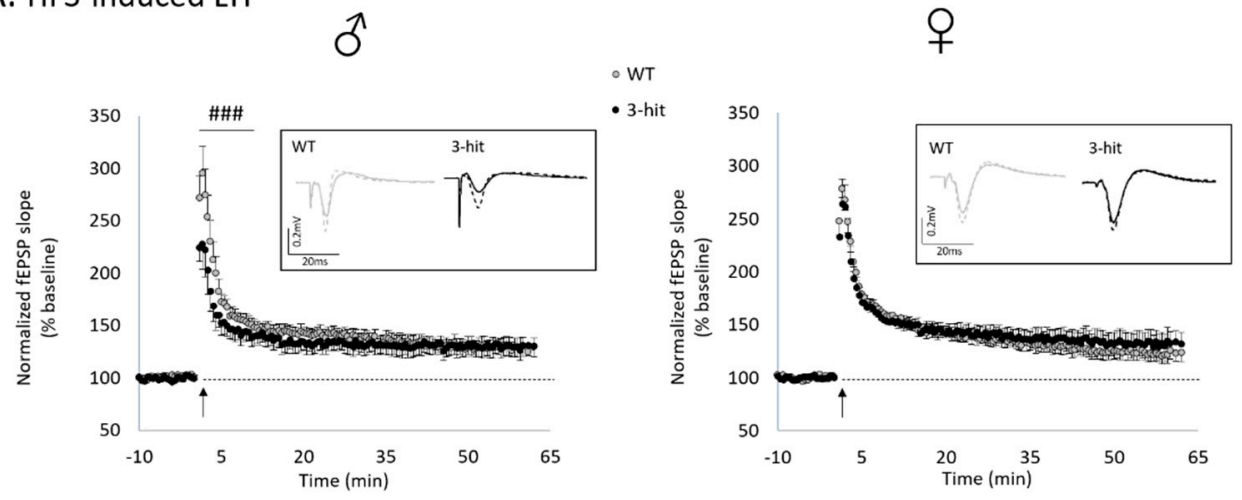

B. TBS-induced LTP
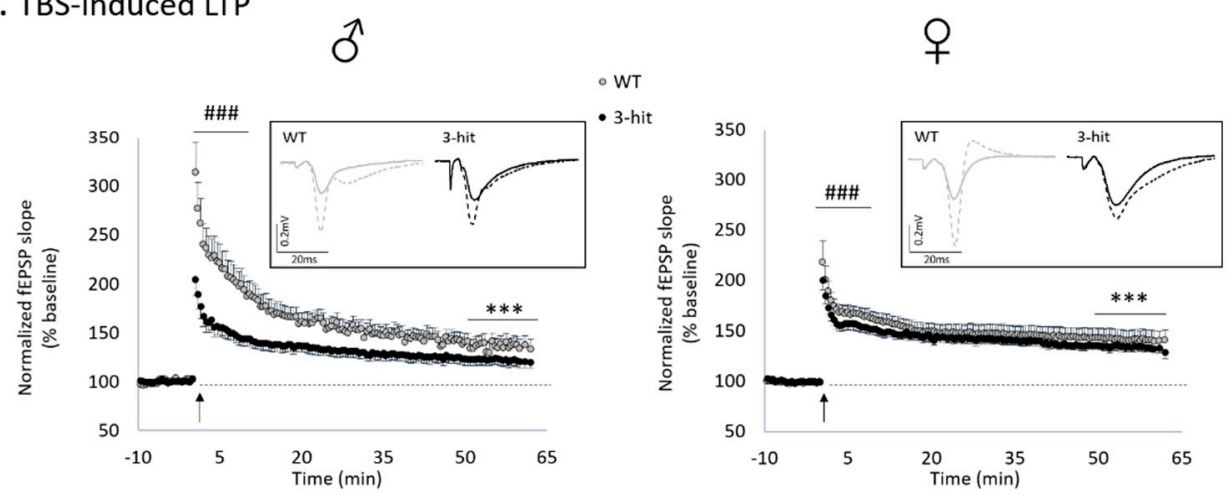

Figure 2. Functional plasticity is altered in 3-hit mice according to stimulation protocols, sex and/or the timing of potentiation. (A) Time-course of high frequency stimulation (HFS)-induced long-term potentiation (LTP) in WT and 3-hit mice, males (left) (WT: $\mathrm{n}=13$ slices vs. 3-hit group $\mathrm{n}=11$ slices) and females (right) (WT: $\mathrm{n}=13$ slices vs. 3-hit: $\mathrm{n}=12$ slices). (B) Time-course of theta-burst stimulation (TBS)-induced LTP in WT and 3-hit mice, males (left) (WT: $\mathrm{n}=26$ slices vs. 3-hit group $\mathrm{n}=13$ slices) and females (right) (WT: $\mathrm{n}=35$ slices vs. 3-hit: $\mathrm{n}=21$ slices). In inserts, examples of traces recorded in a WT and a 3-hit mouse before (filled line) and $60 \mathrm{~min}$ after (dashed line) the conditioning stimulation. Represented data are Mean \pm SEM; non-parametric permutation test (group and time effect), group effect ${ }^{* *}: p<0.001$ (last 15 min). ANOVA with permutation tests for STP, group effect \#\#\#: $p<0.001$ (first $10 \mathrm{~min}$ ).

\subsection{NMDAr Activation}

Considering the pivotal role of NMDAr in the induction and expression of short- and long-term functional plasticity at synapses of neuronal networks, we looked for changes in NMDAr activation in males and females of the different experimental groups. This was achieved by comparing fEPSPs isolated in low $\mathrm{Mg}^{2+}$ medium supplemented with the non-NMDAr antagonist NBQX $(10 \mu \mathrm{M})$.

In these conditions, long-lasting fEPSPs specifically mediated by NMDAr were recorded (Figure 3A). Interestingly, a sexual dimorphism was observed since the Ise was not impacted in 3-hit males compared to WT regardless of the intensity of stimulation, whereas it was significantly higher in females $(p<0.001)$, indicating a specific genderrelated enhancement of NMDAr activation (Figure 3B). No difference between male and female WTs was shown. However, as displayed in Figure 3, females 3-hit have higher NMDAr-mediated synaptic efficacy ratio than males 3-hit $(p<0.001)$. 


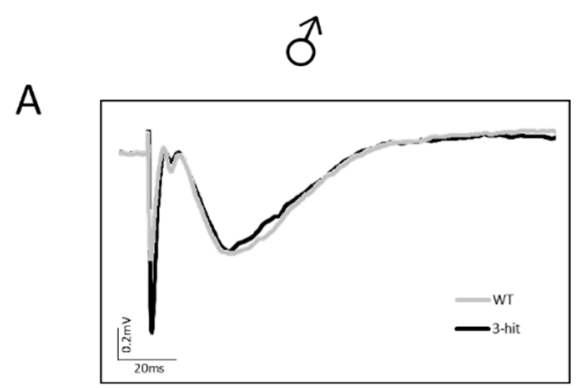

B

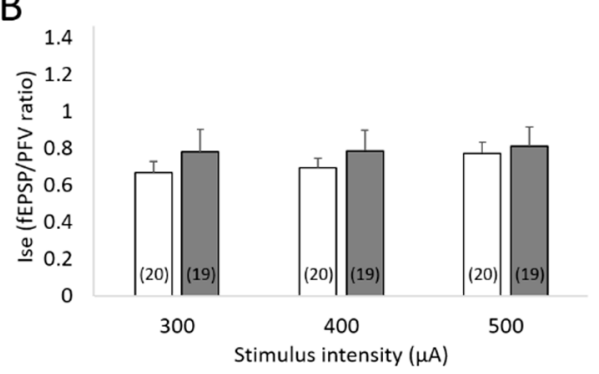

우

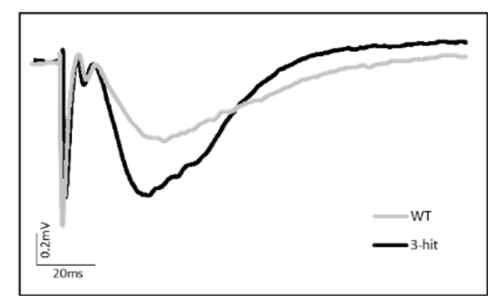

$\square$ WT

$\square$-hit

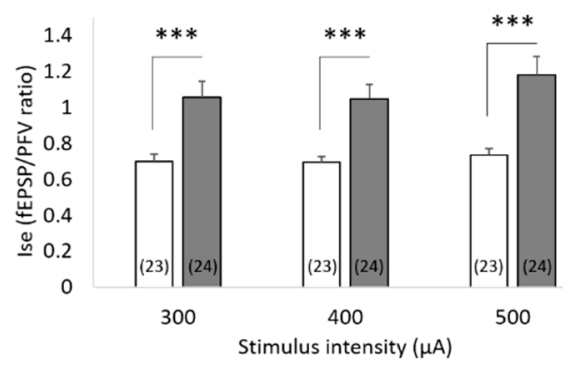

Figure 3. (A) NMDAr activation is specifically enhanced in female 3-hit mice. Superimposed traces of long lasting NMDArinduced fEPSPs recorded in a slice from a male (left) and a female (right), WT (grey line) and a 3-hit (black line) mouse. (B) NMDAr-mediated synaptic efficacy ratio Ise (fEPSP/PFV ratio) in WT and 3-hit male (left) and female (right) mice with increasing stimulus intensity. Number of slices per group are indicated in histogram bars. Represented data are Mean \pm SEM; ANOVA or ANOVA with permutation tests, ${ }^{* * *}: p<0.001$

In the CA1 hippocampal area, NMDAr activation requires the binding of the coagonist D-serine in addition to glutamate [18]. Since the basal excitatory neurotransmission was not affected in 3-hit mice, one may consider that synaptic availability of glutamate was not impacted in those animals. An altered occupancy of the NMDAr co-agonist binding site by D-serine could then induce changes in NMDAr activation. To test this possibility, a saturating concentration of D-serine $(100 \mu \mathrm{M})$ was added to the artificial cerebrospinal fluid (aCSF) [19]. Consequently, a significant increase in Ise was observed in all experimental groups regardless of the intensity of stimulation $(p<0.05)$ (Figure $4 \mathrm{~A})$. The percentage increase by exogenous D-serine was similar in male and female WT and 3-hit mice (Figure S1A), indicating that the occupancy level of the NMDAr glycine binding sites was not impacted by the 3-hit conditioning. Furthermore, it is interesting to note that in this condition of maximal recruitment of NMDAr, no statistical differences in the Ise were found between WT and 3-hit male mice whereas it remained significantly higher in 3-hit females (Figure S2) $(p<0.05)$, suggesting that the synaptic NMDAr density could be altered in the 3-hit model depending on the gender.

We found that HFS- and TBS-induced LTP were differentially impacted in male and female 3-hit mice. Considering that the regulation by GABA inhibitory tone is different for the expression of these two forms of long-lasting synaptic potentiation [20], we looked for changes in inhibition by comparing the effects of pharmacological $\mathrm{GABA}_{\mathrm{A}}$ receptor blockade on NMDAr activation. Adding the $\mathrm{GABA}_{\mathrm{A}}$ receptor antagonist bicuculline $(10 \mu \mathrm{M})$ to the low $\mathrm{Mg}^{2+}$ and NBQX-supplemented aCSF increased the Ise in both male and female WT groups, regardless of the intensity of stimulation (Figure $4 \mathrm{~B}$ and Figure $\mathrm{S1B})$. On the contrary, the Ise was not impacted by bicuculline administration in both male and female 3-hit mice (Figure 4B and Figure S1B), suggesting a decrease in the inhibitory tone in the animal model. 


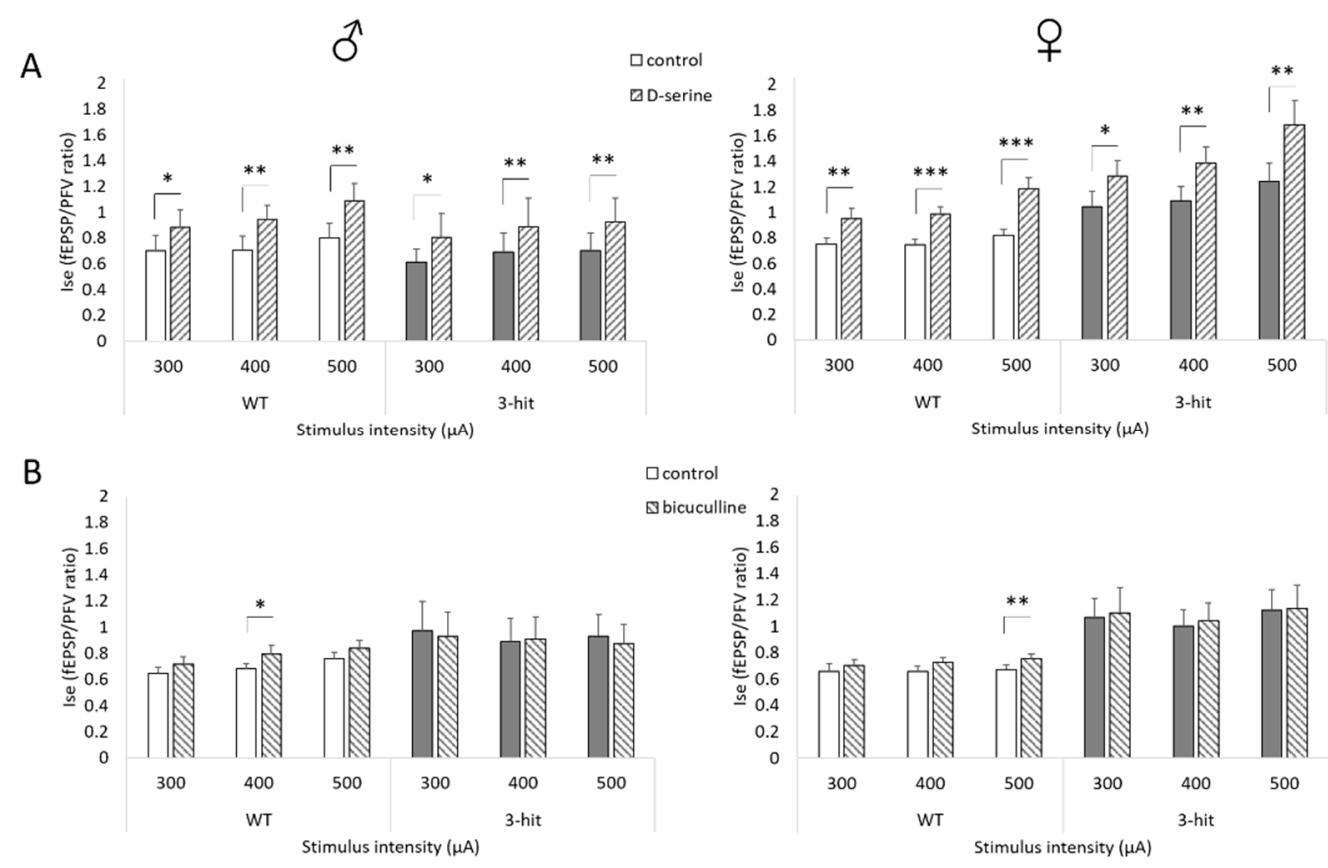

Figure 4. Responsiveness of NMDAr activation to bicuculline but not D-serine is altered in 3-hit mice. (A) Index of NMDArmediated synaptic efficacy Ise (fEPSP/PFV ratio) determined in slices from WT and 3-hit male (left) and female (right) mice, with increasing stimulus intensity, in control vs. D-serine supplemented artificial cerebrospinal fluid (aCSF) (males: WT: $\mathrm{n}=18$ slices vs. 3-hit: $\mathrm{n}=20$ slices; females: WT: $\mathrm{n}=12$ slices vs. 3-hit: $\mathrm{n}=10$ slices). (B) Index of NMDAr-mediated synaptic efficacy Ise (fEPSP/PFV ratio) determined in slices from WT and 3-hit male (left) and female (right) mice, with increasing stimulus intensity, in control vs. bicuculline supplemented aCSF (males: WT: $\mathrm{n}=11$ slices vs. 3-hit: $\mathrm{n}=9$ slices; females: WT: $\mathrm{n}=13$ slices vs. 3-hit: $\mathrm{n}=12$ slices). Represented data are Mean \pm SEM; Paired t-tests or Wilcoxon paired t tests, ${ }^{*}: p<0.05 ;{ }^{* *}: \mathrm{p}<0.01 ; * * *: p<0.001$.

\section{Discussion}

This electrophysiological study investigated the 3-hit model of schizophrenia-like phenotype that has been recently described [12] associating three major risk factors including a genetic susceptibility, an early stressful event, and a late pharmacological insult. We report selective functional deficits (dysregulation of NMDAr- and GABA-related processes) in male and female 3-hit mice that recapitulate several neurotransmission system alterations that have been related to the schizophrenia-like phenotype, thus reinforcing the face validity of the animal model $[7,21,22]$.

The 3-hit model was based on a combination of genetic, environmental, and pharmacological risk factors. Each of these factors is not known to be sufficient per se to reproduce all aspects of the disorder, but are supposed to generate a more extensive pathology if they are associated [23]. Although a lot of studies showed a substantial role of genetic susceptibility on schizophrenia prevalence [24,25], whether one particular gene locus in the patients' genome is essential remains unknown. In the 3-hit model, a partial deletion of the MAP6 gene, which regulates the intracellular microtubule organization $[13,26]$ was selected rather than a complete knock-out, considering that heterozygous MAP6 mice present slight cognitive and social deficits $[13,27,28]$. Indeed, complete deletion of MAP6 drives severe behavioral and functional disturbances mimicking symptoms of psychosis [29-31]. Additionally, environmental perturbations in childhood have been correlated to a stronger risk to develop a psychiatric disease [32,33]. An early maternal separation in rodents thus disturbs brain development and adult behavior [14,34,35]. Furthermore, a decrease in social interaction after maternal separation for $24 \mathrm{~h}$ was reported in mice [34]. Therefore, maternal separation at PND9 for $24 \mathrm{~h}$ was retained for the 3-hit model. Finally, THC administrations from PND32 to PND52 were used as a third factor in the 3-hit model since cannabis increases the risk of developing psychotic-like symptoms in case of chronic 
consumption during adolescence [36,37]. In rodents, deleterious effects of adolescent exposure with cannabinoid receptor 1 agonists have been reported in adult behavior (see review [38]), and THC administration affects long-term memory and increases anxiety states [39]. Furthermore, THC adolescent exposure is widely used in rodent schizophrenia models as a single factor [40] or in combination with another factor [17].

The present electrophysiological study first indicates that the 3-hit conditioning does not significantly affect the basal synaptic transmission mediated by non-NMDAr, i.e., AMPA subtype of glutamate receptors, in CA1 hippocampal networks. This is strengthened by the absence of changes in PPF, indicating that presynaptic release of glutamate is not altered.

Regarding functional plasticity, contradictory results exist in the literature. Transcranial magnetic stimulation showed a reduced LTP-like plasticity in the cortex of schizophrenic patients [41,42]. In rodent models of schizophrenia, some studies reported a weaker hippocampal LTP after social isolation [43], deletion of dysbidin-1 [44], or treatment with the NMDAr antagonist MK801 [45], whereas an increase in LTP has been reported after deletion of DISC1 [46]. What is more, no change was found in rats after prenatal injection of methylazoxymethanol acetate, a neurodevelopmental model of schizophrenia [47]. Finally, different consequences on functional plasticity depending on stimulation protocols have been reported [48], more particularly in rodent models of schizophrenia [49,50]. In the present study, we observed changes in the expression of functional plasticity in 3-hit mice depending not only on the strength of the conditioning stimulation but also on the gender of the animals and/or the type of plasticity (STP vs. LTP). Indeed, HFS-induced LTP was unchanged in 3-hit mice, whereas the expression of TBS-induced long-lasting potentiation was reduced regardless of the gender of the animals. This last result is consistent with Chalkiadaki et al. [51] investigating a developmental model of schizophrenia using methylazoxymethanol administration during gestation in mice. One striking difference between the HFS and TBS stimulation paradigms is the impact of GABA modulation that is critical for TBS but not HFS-induced LTP to be expressed [20]. In contrast to WT, we found that NMDAr activation in 3-hit mice was not affected by GABA receptor blockade with the $\mathrm{GABA}_{\mathrm{A}}$ antagonist bicuculline, suggesting a failure of inhibitory influences in CA1 neuronal networks. In control conditions, presynaptic $G_{A B A}$ autoreceptors are critically involved in the TBS-induced LTP, allowing a long-lasting potentiation to develop by substantially diminishing GABA release [20]. If GABA availability is compromised in 3-hit mice, we could speculate that a weaker activation of $G_{A B A}$ autoreceptors could promote a potent inhibition to persist during the TBS delivery, thus reducing the expression of subsequent LTP. Specific changes in $\mathrm{GABA}_{\mathrm{B}}$ receptor activation now need to be determined in 3-hit mice. However, since MAP6 knock-out mice showed a decrease in vesicle density in presynaptic terminals in the CA1 area [29], alteration of presynaptic release during the TBS delivery cannot be definitively ruled out, although there were no changes in the PPF paradigm of glutamate release in 3-hit mice.

It is interesting to note that the impaired GABA regulation of hippocampal network functioning could be linked to an attenuated PPI response [52,53]. This key behavioral feature, that characterizes animal models of schizophrenia, has been recently described in 3-hit mice (see supplementary data of Bouet et al. (2020)) [12] and represents a behavioral correlation to the present functional deregulation, also seen in MAP6 knock-out mice [54].

We found that HFS-induced LTP was not altered in 3-hit mice. In this paradigm of much stronger conditioning stimulation than the TBS, the contribution of GABA regulation is minimized and the number of NMDAr per se located at synaptic connections is the critical parameter that governs the magnitude of the potentiation. Interestingly, a greater maximal isolated NMDAr activation was found in 3-hit mice but only in females, possibly reflecting a higher synaptic receptor density. Gender-related differences are gaining more and more importance in preclinical studies [16,17], and some sexual dimorphisms have been shown in hippocampal plasticity [55-58]. Even if synaptic NMDAr activity increased in female 3-hit mice, this facilitation did not change the level of HFS-induced LTP. Further- 
more, we showed that only male but not female 3-hit mice displayed a lower short-term potentiation in the HFS protocol. Whether STP and LTP are two independent forms of functional plasticity, and may be associated with distinct aspects of memory formation, remains an open issue [59]. However, their differential alterations could contribute, at least in part, to the sexual dimorphism associated with schizophrenia-like cognitive deficits. Indeed, whatever the direction in changes affecting the expression of functional plasticity in neuronal networks of 3-hit mice, it is interesting to note that they parallel with alterations of hippocampus-related behaviors. In fact, these mice display working and reference memory impairments, sociability deficits, and PPI impairments [12], that were currently associated with hippocampal structural alterations and dysfunctions [52,53,60-64].

In conclusion, we provide evidence of functional impairments of hippocampal networks (inhibitory dysregulation and impaired glutamate-related synaptic plasticity) in 3-hit mice displaying deficits generally associated with the pathophysiology of schizophrenia $[41-45,65,66]$. Multifactorial models such as the 3-hit model used here, certainly represent the future for preclinical studies of psychiatric disorders and therefore appear as the best strategy for the development of more relevant human medication, notably those targeting the GABAergic and glutamatergic systems.

\section{Materials and Methods}

Experiments were performed in accordance with French and European Economic Community guidelines for the care and use of laboratory animals (2010/63/UE, project $\mathrm{n}^{\circ}$ 2019050617054190_v2, date of approval 2019/09/18). All efforts were made to minimize the number of animals used as well as their suffering. In the present study, a total of 42 mice were used, 14 males and 10 females Wild Type (WT), and 6 males and 12 females 3-hit.

\subsection{Genetic Susceptibility}

Heterozygous MAP6 (MAP6+/-) and WT mice were obtained from breeding between male MAP6+/ - mice (129svPas/C57BL/6 strain, from Centre Universitaire de Ressources Biologiques de l'Université de Caen Normandie (CURB), France) and female WT mice (C57BL / 6 strain, from Janvier Labs, France). Animals were kept in groups of 3 to 5 individuals in a reversed $12 \mathrm{~h} / 12 \mathrm{~h}$ light/dark cycle (light on at 19 p.m., off at 7 a.m.), with regulated temperature $\left(21 \pm 1{ }^{\circ} \mathrm{C}\right)$ and humidity $(55 \pm 10 \%)$. Food and water were given ad libitum. At weaning, mice were identified with a subcutaneous chip placed under anaesthesia (isoflurane (5-2.5\%) in an $\mathrm{O}_{2} / \mathrm{N}_{2} \mathrm{O}$ mixture (0.3/0.7)), and tail sampling was performed for genotyping [13].

\subsection{Maternal Separation (MS)}

Half of the litters were separated from their mother for a single period of $24 \mathrm{~h}$ on the 9th post-natal day (PND9). The mothers were removed and individually placed near the pups in another cage from 9:00 a.m. to 9:00 a.m. the following day. Then, the mothers were returned to their litters and left undisturbed until weaning. Control mice were submitted to the same protocol but separated for only $20 \mathrm{~s}[14,34]$.

\section{3. $\Delta$-9-Tetrahydrocannabinol Treatment}

Tetrahydrocannabinol (THC, Sigma Aldrich ${ }^{\circledR}$, Lyon, France) was dissolved in a vehicle saline solution ( $0.9 \%$ ) with polysorbate 80 (Tween 80 , Sigma-Aldrich, Steinheim, Germany, $3.5 \%$ ) to obtain a final dose of $8 \mathrm{mg} / \mathrm{kg}$ [15]. The 3-hit mice received daily intraperitoneal THC solution (at 5:00 pm) from PND32 to PND52 while WT mice received the vehicle (3.5\% Tween 80 in saline solution).

\subsection{Ex Vivo Electrophysiology}

Between PND140 to PND256, mice were anesthetized with isoflurane and decapitated. The brain was rapidly removed from the skull and placed in chilled $\left(-3\right.$ to $\left.0{ }^{\circ} \mathrm{C}\right)$ artificial cerebrospinal fluid (aCSF) containing $124 \mathrm{mM} \mathrm{NaCl}, 3 \mathrm{mM} \mathrm{KCl}, 1.5 \mathrm{mM} \mathrm{MgSO}_{4}, 2.5 \mathrm{mM}$ 
$\mathrm{CaCl}_{2}, 26.2 \mathrm{mM} \mathrm{NaHCO}_{3}, 1.2 \mathrm{mM} \mathrm{NaH}_{2} \mathrm{PO}_{4}$, and $11 \mathrm{mM}$ glucose. Transverse slices $(400 \mu \mathrm{m}$ thick) of both ventral and dorsal part of the hippocampus were obtained with a slicer (Mc Ilwain ${ }^{\circledR}$ ) and placed in aCSF in a holding chamber, at $28^{\circ} \mathrm{C}$, for at least one hour before recordings [67]. A slice was then transferred to a submersion-type recording chamber and continuously perfused at room temperature with aCSF equilibrated with $95 \% \mathrm{O}_{2}$, $5 \% \mathrm{CO}_{2}$. Extracellular recordings were obtained from glass micropipettes (2-5 $\mathrm{M} \Omega$ ) filled with $2 \mathrm{M} \mathrm{NaCl}$ positioned in the stratum radiatum of the CA1 hippocampal area. PFVs and non-NMDA-mediated fEPSPs were evoked in control aCSF by electrical stimulation of the Schaffer collaterals/commissural pathway located in the stratum radiatum. The slope of three successive PFVs and fEPSPs was determined using WinLTP ${ }^{\circledR}$ software [68-70]. To evaluate the level of synaptic activation, an index of synaptic efficacy (Ise) corresponding to the fEPSP/PFV ratio was calculated and plotted systematically against stimulus intensity $(300,400$ and $500 \mu \mathrm{A})$. Paired-pulse facilitation (PPF) of synaptic transmission was then induced to investigate possible changes in presynaptic mechanisms of glutamate release using paired pulse with inter-stimulus interval of $30 \mathrm{~ms}$. PPF was determined as the ratio of the slope of the second response over that of the first fEPSP. In addition, specific NMDA receptor (NMDAr) activation was evaluated by recording fEPSPs pharmacologically isolated from slices perfused with aCSF containing low $\mathrm{Mg}^{2+}(0.1 \mathrm{mM})$ and supplemented with the non-NMDAr antagonist 2,3-dioxo-6-nitro-1,2,3,4-tetrahydrobenzoquinoxaline-7-

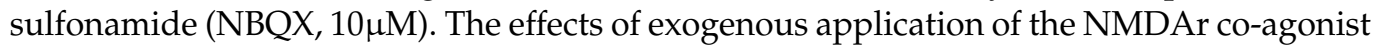
D-serine $(100 \mu \mathrm{M})$ or the $\mathrm{GABA}_{\mathrm{A}}$ receptor antagonist bicuculline $(10 \mu \mathrm{M})$ were assessed by comparing the fEPSP/PFV ratio before and $15 \mathrm{~min}$ after the addition of the drug to the aCSF.

In order to investigate long-term potentiation (LTP) and short-term potentiation (STP) of synaptic transmission, a test stimulus was applied every $10 \mathrm{~s}$ in control medium and adjusted to get a fEPSP with a baseline slope of $0.1 \mathrm{~V} / \mathrm{s}$. The averaged slope of $3 \mathrm{fEPSPs}$ was measured for $15 \mathrm{~min}$ before the delivery of a high-frequency stimulation (HFS), consisting of 1 burst at $100 \mathrm{~Hz}$ pulses delivered for $1 \mathrm{~s}$. In another set of experiments, a thetaburst stimulation (TBS) was delivered, consisting of 4 successive sequences delivered at $0.1 \mathrm{~Hz}$. Each sequence consisted in 5 bursts separated from each other by $200 \mathrm{~ms}(5 \mathrm{~Hz})$. Within each burst, 4 impulses were delivered at $100 \mathrm{~Hz}$ [48]. In both HFS and TBS-related experiments, testing with single pulse was then resumed for $60 \mathrm{~min}$ to determine the level of potentiation. STP was quantified by comparing the first $10 \mathrm{~min}$ after the stimulation to the baseline while LTP was quantified with the last $15 \mathrm{~min}$ of recording, e.g., between 45 and $60 \mathrm{~min}$ after the conditioning stimulation.

All pharmacological agents were diluted directly in the perfusion medium from stock solutions prepared in distilled water. All drugs were purchased from Tocris Bioscience ${ }^{\circledR}$ (Bristol, UK).

\subsection{Data Analysis}

Statistical analyses were performed using R software 3.6.2 (Free Software Foundation, Vienna, Austria; R Development Core team 2009). Shapiro tests were used to assess data normality. When data were normally distributed, ANOVAs were used for group comparisons, and paired t-tests to assess drugs effects. When data were not normally distributed, ANOVAs with permutations were used for group comparison, and Wilcoxon paired tests to assess drugs effects. Concerning LTP and STP analyses, group comparisons were performed with non-parametric permutation test ezPerm function with time effect (package "ez"). Differences were considered significant when the associated $\mathrm{p}$ value was below 0.05 .

Supplementary Materials: The following are available online at https:/ /www.mdpi.com/1422-006 7/22/5/2644/s1, Figure S1: Increase in NMDAr activation by exogenous bicuculline but not D-serine is lower in 3-hit mice, Figure S2: Maximal synaptic NMDAr activation is higher in female 3-hit mice. 
Author Contributions: Conceptualization, J.-M.B., T.F., M.B. and V.B.; Data curation, S.P. and J.-M.B.; Writing-original draft, S.P. and J.-M.B.; Writing—review and editing, S.P., J.-M.B., T.F., A.A., M.B. and V.B. All authors have read and agreed to the published version of the manuscript.

Funding: This work was supported by the University of Caen Normandy, Normandy Region, INSERM and UNAFAM. The authors declare no conflict of interest.

Institutional Review Board Statement: Experiments were performed in accordance with French and European Economic Community guidelines for the care and use of laboratory animals (2010/63/UE, project $n^{\circ}$ 2019050617054190_v2, date of approval 18 September 2019).

Informed Consent Statement: Not applicable.

Data Availability Statement: The data presented in this study are available on request from the corresponding author. The data are not publicly available because they belong to our funding.

Acknowledgments: We are grateful to Nicole Turnbull, as native English-speaker, who accepted to proofread the present manuscript.

Conflicts of Interest: The authors declare no conflict of interest.

\section{References}

1. Addington, J.; Addington, D.; Maticka-Tyndale, E. Cognitive functioning and positive and negative symptoms in schizophrenia. Schizophr. Res. 1991, 5, 123-134. [CrossRef]

2. Murphy, B.P.; Chung, Y.-C.; Park, T.-W.; McGorry, P.D. Pharmacological treatment of primary negative symptoms in schizophrenia: A systematic review. Schizophr. Res. 2006, 88, 5-25. [CrossRef] [PubMed]

3. Krogmann, A.; Peters, L.; Von Hardenberg, L.; Bödeker, K.; Nöhles, V.B.; Correll, C.U. Keeping up with the therapeutic advances in schizophrenia: A review of novel and emerging pharmacological entities. CNS Spectr. 2019, 24, 38-69. [CrossRef] [PubMed]

4. Bouet, V.; Boulouard, M.; Freret, T. Animal models of schizophrenia: An update. In Advances in Schizophrenia Research; Normandie University: Caen, France, 2016; Available online: www.openaccessebooks.com (accessed on 21 September 2020).

5. Ellenbroek, B.A.; Riva, M.A. Early maternal deprivation as an animal model for schizophrenia. Clin. Neurosci. Res. 2003, 3, 297-302. [CrossRef]

6. Jones, C.A.; Watson, D.J.G.; Fone, K.C.F. Animal models of schizophrenia. Br. J. Pharmacol. 2011, 164, 1162-1194. [CrossRef]

7. Millan, M.J.; Andrieux, A.; Bartzokis, G.; Cadenhead, K.; Dazzan, P.; Fusar-Poli, P.D.P.; Gallinat, J.; Giedd, J.; Grayson, D.R.; Heinrichs, M.; et al. Altering the course of schizophrenia: Progress and perspectives. Nat. Rev. Drug Discov. 2016, 15, 485-515. [CrossRef] [PubMed]

8. Yanagi, M.; Southcott, S.; Lister, J.; Tamminga, C.A. Animal Models of Schizophrenia; Elsevier: Amsterdam, The Neatherlands, 2012; Volume 105, pp. 411-444.

9. Moran, P.; Stokes, J.; Marr, J.; Bock, G.; Desbonnet, L.; Waddington, J.; O'Tuathaigh, C. Gene $\times$ environment interactions in schizophrenia: Evidence from genetic mouse models. Neural Plast. 2016, 2016, 1-23. [CrossRef]

10. Ayhan, Y.; McFarland, R.; Pletnikov, M.V. Animal models of gene-environment interaction in schizophrenia: A dimensional perspective. Prog. Neurobiol. 2016, 136, 1-27. [CrossRef]

11. Winship, I.R.; Dursun, S.M.; Baker, G.B.; Balista, P.A.; Kandratavicius, L.; Maia-De-Oliveira, J.P.; Hallak, J.; Howland, J.G. An overview of animal models related to schizophrenia. Can. J. Psychiatry 2018, 64, 5-17. [CrossRef]

12. Bouet, V.; Percelay, S.; Leroux, E.; Diarra, B.; Léger, M.; Delcroix, N.; Andrieux, A.; Dollfus, S.; Freret, T.; Boulouard, M. A new 3-hit mouse model of schizophrenia built on genetic, early and late factors. Schizophr. Res. 2020. [CrossRef]

13. Volle, J.; Brocard, J.; Saoud, M.; Gory-Faure, S.; Brunelin, J.; Andrieux, A.; Suaud-Chagny, M.-F. Reduced expression of STOP/MAP6 in mice leads to cognitive deficits. Schizophr. Bull. 2012, 39, 969-978. [CrossRef]

14. Ellenbroek, B.A.; van den Kroonenberg, P.T.; Cools, A.R. The effects of an early stressful life event on sensorimotor gating in adult rats. Schizophr. Res. 1998, 30, 251-260. [CrossRef]

15. O'Tuathaigh, C.M.P.; Hryniewiecka, M.; Behan, A.T.; Tighe, O.; Coughlan, C.; Desbonnet, L.; Cannon, M.; Karayiorgou, M.; Gogos, J.A.; Cotter, D.R.; et al. Chronic adolescent exposure to $\Delta$-9-tetrahydrocannabinol in COMT mutant mice: Impact on psychosis-related and other phenotypes. Neuropsychopharmacology 2010, 35, 2262-2273. [CrossRef]

16. Leger, M.; Neill, J.C. A systematic review comparing sex differences in cognitive function in schizophrenia and in rodent models for schizophrenia, implications for improved therapeutic strategies. Neurosci. Biobehav. Rev. 2016, 68, 979-1000. [CrossRef]

17. Dunn, A.L.; Michie, P.T.; Hodgson, D.M.; Harms, L. Adolescent cannabinoid exposure interacts with other risk factors in schizophrenia: A review of the evidence from animal models. Neurosci. Biobehav. Rev. 2020, 116, 202-220. [CrossRef] [PubMed]

18. Wolosker, H. D-serine regulation of NMDA receptor activity. Sci. STKE 2006, 2006, pe41. [CrossRef] [PubMed]

19. Junjaud, G.; Rouaud, E.; Turpin, F.; Mothet, J.-P.; Billard, J.-M. Age-related effects of the neuromodulator d-serine on neurotransmission and synaptic potentiation in the CA1 hippocampal area of the rat. J. Neurochem. 2006, 98, 1159-1166. [CrossRef] [PubMed] 
20. Gong, N.; Li, Y.; Cai, G.-Q.; Niu, R.-F.; Fang, Q.; Wu, K.; Chen, Z.; Lin, L.-N.; Xu, L.; Fei, J.; et al. GABA transporter-1 Activity modulates hippocampal theta oscillation and theta burst stimulation-induced long-term potentiation. J. Neurosci. 2009, 29, 15836-15845. [CrossRef] [PubMed]

21. McCutcheon, R.A.; Krystal, J.H.; Howes, O.D. Dopamine and glutamate in schizophrenia: Biology, symptoms and treatment. World Psychiatry 2020, 19, 15-33. [CrossRef]

22. Xu, M.-Y.; Wong, A.H.C. GABAergic inhibitory neurons as therapeutic targets for cognitive impairment in schizophrenia. Acta Pharmacol. Sin. 2018, 39, 733-753. [CrossRef] [PubMed]

23. Sultana, R.; Lee, C.C. Expression of behavioral phenotypes in genetic and environmental mouse models of schizophrenia. Front. Behav. Neurosci. 2020, 14, 1-12. [CrossRef]

24. Tsuang, M. Schizophrenia: Genes and environment. Biol. Psychiatry 2000, 47, 210-220. [CrossRef]

25. Ripke, S.; Neale, B.M.; Corvin, A.; Walters, J.T.R.; Farh, K.-H.; Holmans, P.A.; Lee, P.; Sullvian-Bulik, B.; Collier, D.A.; Huang, H.; et al. Biological insights from 108 schizophrenia-associated genetic loci. Nat. Cell Biol. 2014, 511, 421-427. [CrossRef]

26. Deloulme, J.-C.; Gory-Fauré, S.; Mauconduit, F.; Chauvet, S.; Jonckheere, J.; Boulan, B.; Mire, E.; Xue, J.; Jany, M.; Maucler, C.; et al. Microtubule-associated protein 6 mediates neuronal connectivity through Semaphorin 3E-dependent signalling for axonal growth. Nat. Commun. 2015, 6, 7246. [CrossRef] [PubMed]

27. Merenlender-Wagner, A.; Pikman, R.; Giladi, E.; Andrieux, A.; Gozes, I. NAP (davunetide) enhances cognitive behavior in the STOP heterozygous mouse-A microtubule-deficient model of schizophrenia. Peptides 2010, 31, 1368-1373. [CrossRef]

28. Merenlender-Wagner, A.; Shemer, Z.; Touloumi, O.; Lagoudaki, R.; Giladi, E.; Andrieux, A.; Grigoriadis, N.C.; Gozes, I. New horizons in schizophrenia treatment: Autophagy protection is coupled with behavioral improvements in a mouse model of schizophrenia. Autophagy 2014, 10, 2324-2332. [CrossRef]

29. Andrieux, A.; Salin, P.A.; Vernet, M.; Kujala, P.; Baratier, J.; Gory-Fauré, S.; Bosc, C.; Pointu, H.; Proietto, D.; Schweitzer, A.; et al. The suppression of brain cold-stable microtubules in mice induces synaptic defects associated with neuroleptic-sensitive behavioral disorders. Genes Dev. 2002, 16, 2350-2364. [CrossRef]

30. Bouvrais-Veret, C.; Weiss, S.; Hanoun, N.; Andrieux, A.; Schweitzer, A.; Job, D.; Hamon, M.; Giros, B.; Martres, M.-P. Microtubuleassociated STOP protein deletion triggers restricted changes in dopaminergic neurotransmission. J. Neurochem. 2007, 104, 745-756. [CrossRef] [PubMed]

31. Brenner, E.; Sonnewald, U.; Schweitzer, A.; Andrieux, A.; Nehlig, A. Hypoglutamatergic activity in the STOP knockout mouse: A potential model for chronic untreated schizophrenia. J. Neurosci. Res. 2007, 85, 3487-3493. [CrossRef]

32. Anglin, D.M.; Cohen, P.R.; Chen, H. Duration of early maternal separation and prediction of schizotypal symptoms from early adolescence to midlife. Schizophr. Res. 2008, 103, 143-150. [CrossRef] [PubMed]

33. Mäki, P.; Veijola, J.; Joukamaa, M.; Läärä, E.; Hakko, H.; Jones, P.B.; Isohanni, M. Maternal separation at birth and schizophrenia-a long-term follow-up of the Finnish Christmas Seal Home Children. Schizophr. Res. 2003, 60, 13-19. [CrossRef]

34. Bouet, V.; Lecrux, B.; Tran, G.; Freret, T. Effect of pre- versus post-weaning environmental disturbances on social behaviour in mice. Neurosci. Lett. 2011, 488, 221-224. [CrossRef]

35. Vetulani, J. Early maternal separation: A rodent model of depression and a prevailing human condition. Pharmacol. Rep. 2013, 65, 1451-1461. [CrossRef]

36. Di Forti, M.; Quattrone, D.; Freeman, T.P.; Tripoli, G.; Gayer-Anderson, C.; Quigley, H.; Rodriguez, V.; Jongsma, H.E.; Ferraro, L.; La Cascia, C.; et al. The contribution of cannabis use to variation in the incidence of psychotic disorder across Europe (EU-GEI): A multicentre case-control study. Lancet Psychiatry 2019, 6, 427-436. [CrossRef]

37. Renard, J.; Krebs, M.-O.; Le Pen, G.; Jay, T.M. Long-term consequences of adolescent cannabinoid exposure in adult psychopathology. Front. Neurosci. 2014, 8, 361. [CrossRef] [PubMed]

38. Rubino, T.; Parolaro, D. The Impact of exposure to cannabinoids in adolescence: Insights from animal models. Biol. Psychiatry 2016, 79, 578-585. [CrossRef]

39. Murphy, M.; Mills, S.; Winstone, J.; Leishman, E.; Wager-Miller, J.; Bradshaw, H.; Mackie, K. Chronic adolescent $\Delta 9$ Tetrahydrocannabinol treatment of male mice leads to long-term cognitive and behavioral dysfunction, which are prevented by concurrent cannabidiol treatment. Cannabis Cannabinoid Res. 2017, 2, 235-246. [CrossRef]

40. Zamberletti, E.; Rubino, T. Impact of the endocannabinoid system manipulation on neurodevelopmental processes relevant to schizophrenia. Biol. Psychiatry Cogn. Neurosci. Neuroimaging 2020. [CrossRef]

41. Hasan, A.; Nitsche, M.A.; Rein, B.; Schneider-Axmann, T.; Guse, B.; Gruber, O.; Falkai, P.; Wobrock, T. Dysfunctional long-term potentiation-like plasticity in schizophrenia revealed by transcranial direct current stimulation. Behav. Brain Res. 2011, $224,15-22$. [CrossRef]

42. Frantseva, M.V.; Fitzgerald, P.B.; Chen, R.; Möller, B.; Daigle, M.; Daskalakis, Z.J. Evidence for impaired long-term potentiation in schizophrenia and its relationship to motor skill leaning. Cereb. Cortex 2007, 18, 990-996. [CrossRef]

43. Roberts, L.; Greene, J. Post-weaning social isolation of rats leads to a diminution of LTP in the CA1 to subiculum pathway. Brain Res. 2003, 991, 271-273. [CrossRef]

44. Glen, W.B.; Horowitz, B.; Carlson, G.C.; Cannon, T.D.; Talbot, K.; Jentsch, J.D.; Lavin, A. Dysbindin-1 loss compromises NMDAR-dependent synaptic plasticity and contextual fear conditioning. Hippocampus 2013, 24, 204-213. [CrossRef] 
45. Manahan-Vaughan, D.; Von Haebler, D.; Winter, C.; Juckel, G.; Heinemann, U. A single application of MK801 causes symptoms of acute psychosis, deficits in spatial memory, and impairment of synaptic plasticity in rats. Hippocampus 2008, 18, 125-134. [CrossRef]

46. Booth, C.A.; Brown, J.T.; Randall, A.D. Neurophysiological modification of CA1 pyramidal neurons in a transgenic mouse expressing a truncated form of disrupted-in-schizophrenia 1. Eur. J. Neurosci. 2014, 39, 1074-1090. [CrossRef]

47. Sanderson, T.M.; Cotel, M.-C.; O'Neill, M.J.; Tricklebank, M.D.; Collingridge, G.L.; Sher, E. Alterations in hippocampal excitability, synaptic transmission and synaptic plasticity in a neurodevelopmental model of schizophrenia. Neuropharmacology 2012, 62, 1349-1358. [CrossRef]

48. Larson, J.; Munkácsy, E. Theta-burst LTP. Brain Res. 2015, 1621, 38-50. [CrossRef] [PubMed]

49. Drew, L.J.; Stark, K.L.; Fénelon, K.; Karayiorgou, M.; MacDermott, A.B.; Gogos, J.A. Evidence for altered hippocampal function in a mouse model of the human 22q11.2 microdeletion. Mol. Cell. Neurosci. 2011, 47, 293-305. [CrossRef] [PubMed]

50. Nomura, T.; Oyamada, Y.; Fernandes, H.B.; Remmers, C.L.; Xu, J.; Meltzer, H.Y.; Contractor, A. Subchronic phencyclidine treatment in adult mice increases GABAergic transmission and LTP threshold in the hippocampus. Neuropharmacology 2016, 100, 90-97. [CrossRef] [PubMed]

51. Chalkiadaki, K.; Velli, A.; Kyriazidis, E.; Stavroulaki, V.; Vouvoutsis, V.; Chatzaki, E.; Aivaliotis, M.; Sidiropoulou, K. Development of the MAM model of schizophrenia in mice: Sex similarities and differences of hippocampal and prefrontal cortical function. Neuropharmacology 2019, 144, 193-207. [CrossRef] [PubMed]

52. Hauser, J.; Rudolph, U.; Keist, R.; Möhler, H.; Feldon, J.; Yee, B.K. Hippocampal $\alpha 5$ subunit-containing GABAA receptors modulate the expression of prepulse inhibition. Mol. Psychiatry 2004, 10, 201-207. [CrossRef] [PubMed]

53. Zhang, W.-N.; Bast, T.; Feldon, J. Prepulse inhibition in rats with temporary inhibition/inactivation of ventral or dorsal hippocampus. Pharmacol. Biochem. Behav. 2002, 73, 929-940. [CrossRef]

54. Fradley, R.L.; O'Meara, G.F.; Newman, R.J.; Andrieux, A.; Job, D.; Reynolds, D.S. STOP knockout and NMDA NR1 hypomorphic mice exhibit deficits in sensorimotor gating. Behav. Brain Res. 2005, 163, 257-264. [CrossRef]

55. Jain, A.; Huang, G.Z.; Woolley, C.S. Latent sex differences in molecular signaling that underlies excitatory synaptic potentiation in the hippocampus. J. Neurosci. 2019, 39, 1552-1565. [CrossRef]

56. Brandt, N.; Vierk, R.; Fester, L.; Anstötz, M.; Zhou, L.; Heilmann, L.F.; Kind, S.; Steffen, P.; Rune, G.M. Sex-specific difference of hippocampal synaptic plasticity in response to sex neurosteroids. Cereb. Cortex 2020, 30, 2627-2641. [CrossRef]

57. Wang, W.; Le, A.A.; Hou, B.; Lauterborn, J.C.; Cox, C.D.; Levin, E.R.; Lynch, G.; Gall, C.M. Memory-Related synaptic plasticity is sexually dimorphic in rodent hippocampus. J. Neurosci. 2018, 38, 7935-7951. [CrossRef] [PubMed]

58. Derks, N.A.V.; Krugers, H.J.; Hoogenraad, C.C.; Joëls, M.; Sarabdjitsingh, R.A. Effects of early life stress on synaptic plasticity in the developing hippocampus of male and female rats. PLoS ONE 2016, 11, e0164551. [CrossRef] [PubMed]

59. Lisman, J. Glutamatergic synapses are structurally and biochemically complex because of multiple plasticity processes: Long-term potentiation, long-term depression, short-term potentiation and scaling. Philos. Trans. R. Soc. B Biol. Sci. 2017, 372, 20160260. [CrossRef]

60. Nguyen, R.; Morrissey, M.D.; Mahadevan, V.; Cajanding, J.D.; Woodin, M.A.; Yeomans, J.S.; Takehara-Nishiuchi, K.; Kim, J.C. Parvalbumin and GAD65 interneuron inhibition in the ventral hippocampus induces distinct behavioral deficits relevant to schizophrenia. J. Neurosci. 2014, 34, 14948-14960. [CrossRef] [PubMed]

61. Glover, M.E.; Clinton, S.M. Of rodents and humans: A comparative review of the neurobehavioral effects of early life SSRI exposure in preclinical and clinical research. Int. J. Dev. Neurosci. 2016, 51, 50-72. [CrossRef] [PubMed]

62. Yonelinas, A.P. The hippocampus supports high-resolution binding in the service of perception, working memory and long-term memory. Behav. Brain Res. 2013, 254, 34-44. [CrossRef]

63. Neves, G.; Cooke, S.F.; Bliss, T.V.P. Synaptic plasticity, memory and the hippocampus: A neural network approach to causality. Nat. Rev. Neurosci. 2008, 9, 65-75. [CrossRef] [PubMed]

64. Bures, J.; Fenton, A.A.; Kaminsky, Y.; Zinyuk, L. Place cells and place navigation. Proc. Natl. Acad. Sci. USA 1997, 94, 343-350. [CrossRef] [PubMed]

65. Taylor, S.F.; Tso, I.F. GABA abnormalities in schizophrenia: A methodological review of in vivo studies. Schizophr. Res. 2015, 167, 84-90. [CrossRef]

66. Nakazawa, K.; Zsiros, V.; Jiang, Z.; Nakao, K.; Kolata, S.; Zhang, S.; Belforte, J.E. GABAergic interneuron origin of schizophrenia pathophysiology. Neuropharmacology 2012, 62, 1574-1583. [CrossRef] [PubMed]

67. Potier, B.; Poindessous-Jazat, F.; Dutar, P.; Billard, J.M. NMDA receptor activation in the aged rat hippocampus. Exp. Gerontol. 2000, 35, 1185-1199. [CrossRef]

68. Anderson, W.W.; Collingridge, G.L. The LTP Program: A data acquisition program for on-line analysis of long-term potentiation and other synaptic events. J. Neurosci. Methods 2001, 108, 71-83. [CrossRef]

69. Anderson, W.W.; Collingridge, G.L. Capabilities of the WinLTP data acquisition program extending beyond basic LTP experimental functions. J. Neurosci. Methods 2007, 162, 346-356. [CrossRef] [PubMed]

70. Lecouflet, P.; Roux, C.M.; Potier, B.; Leger, M.; Brunet, E.; Billard, J.-M.; Schumann-Bard, P.; Freret, T. Interplay between 5-HT4 receptors and GABAergic system within CA1 hippocampal synaptic plasticity. Cereb. Cortex 2021, 31, 694-701. [CrossRef] 